\title{
27. METAMORPHISM AND ALTERATION IN OCEANIC LAYER 3: HOLE 735B1
}

\author{
Paul T. Robinson, ${ }^{2}$ Henry J. B. Dick, ${ }^{3}$ and Richard Von Herzen ${ }^{3}$
}

\begin{abstract}
A 500-m-thick section of gabbros drilled at Site 735 on the flank of the Southwest Indian Ridge provides the first opportunity to assess the nature and depth of metamorphism and alteration in oceanic layer 3 . Five styles of metamorphism/alteration are recognized: granulite to amphibolite facies metamorphism accompanying brittleductile deformation; static replacement of olivine and orthopyroxene by $\mathrm{Mg}$-amphiboles, talc, and magnetite; inclined vein filling; subvertical crack filling; and late-stage oxidation of olivine and pyroxene. Temperatures ranged from a high of about $720^{\circ} \mathrm{C}$ during metamorphism to probably less than $25^{\circ} \mathrm{C}$ during oxidative alteration. Many inclined veins contain disequilibrium or sequential assemblages, reflecting decreasing temperatures and changing fluid compositions. Fluid/rock ratios ranged from low to high and were largely dependent on the extent of brittle-ductile deformation. In general, hydration of the rocks was accompanied by increases in $\mathrm{CO}_{2}, \mathrm{~K}_{2} \mathrm{O}$, and ferric iron, but variations are not always consistent.

The early high-temperature metamorphism and static alteration probably took place while the crustal segment was beneath the median rift of the Southwest Indian Ridge. The brittle-ductile deformation is believed to reflect listric normal faulting during crustal accretion. After about $500,000 \mathrm{yr}$, the crustal segment would have migrated out of the median valley into the rift valley walls, and this uplift may have been responsible for formation of the inclined veins or may have at least caused earlier veins to be reopened. Vertical crack formation and late-stage oxidation may reflect uplift of the crustal block to its present position in the transverse ridge along the Atlantis II Fracture Zone, approximately $1 \mathrm{Ma}$. Crustal attenuation by listric faulting and later wave erosion were probably responsible for exposing the section to the seafloor.
\end{abstract}

\section{INTRODUCTION}

Determining the nature and extent of alteration in layer 3 is of critical importance to our understanding of hydrothermal processes at spreading ridges and for assessing the composition of crustal sections that enter subduction zones. Until recently, information about alteration in the lower oceanic crust was obtained either from studying ophiolites or samples exposed on the seafloor by tectonic processes. Most ophiolites are now viewed as having been formed in supra-subduction zone environments and, hence, are not considered representative of typical oceanic crust. Samples of oceanic layer 3 obtained from the seafloor typically are from fault zones, where alteration is likely to be considerably greater than normal.

During Leg 118, scientists on board the JOIDES Resolution drilled a $500.7-\mathrm{m}$-deep hole into layer 3 of the oceanic crust, achieving nearly $87 \%$ core recovery. Thus, for the first time, scientists have the opportunity to examine the nature and extent of alteration in a coherent section of layer 3 and to assess the nature of deep hydrothermal fluids in the oceanic crust. Members of the shipboard scientific party undertook mineralogical, petrographic, isotopic, and geochemical studies to answer a number of specific questions: (1) At what stage of crustal evolution does seawater penetrate the crust and to what depths does it reach? (2) What were the temperatures and compositions of the fluids involved and how did they evolve through time? (3) What secondary minerals are present in the lower crust and how has their development changed the physical and chemical character of the primary rocks? Here,

\footnotetext{
${ }^{1}$ Von Herzen, R. P., Robinson, P. T., et al., 1991. Proc. ODP, Sci. Results, 118: College Station, TX (Ocean Drilling Program).

2 Centre for Marine Geology, Dalhousie University, Halifax, Nova Scotia, Canada B3H 3 J5.

${ }^{3}$ Department of Geology and Geophysics, Woods Hole Oceanographic Institution, Woods Hole, MA 02543, U.S.A.
}

we attempt to summarize some of the data obtained and to present preliminary answers to these questions. We also attempt to integrate these data into a generalized model for alteration of this particular section of deep oceanic crust. This chapter is not intended to be an exhaustive summary of all work reported in this volume; rather, it is based on personal observations of the authors and on selected data from the cited chapters.

\section{Tectonic Setting}

Site 735 is located on a shallow platform atop the transverse ridge that lies along the east rim of the Atlantis II Fracture Zone, on the Southwest Indian Ridge. The platform is one of a series of uplifted blocks and intervening saddles lying parallel to the axis of the transform. This platform has a relatively flat surface, approximately $5 \times 2 \mathrm{~km}$ wide, which is underlain by foliated metagabbro lightly mantled with sediment.

The site lies between magnetic anomalies 5 and $5 \mathrm{a}$, approximately $93 \mathrm{~km}$ south of the present-day axis of the Southwest Indian Ridge and $18 \mathrm{~km}$ from the inferred axis of transform faulting on the Atlantis II Fracture Zone (Dick et al., this volume). A reconstruction based on the spreading direction indicates that the section formed beneath the median valley of the Southwest Indian Ridge about 15 to $19 \mathrm{~km}$ from the ridgetransform intersection. This proximity to a major transform fault may have resulted in a relatively thin crustal section (cf. Detrick and Purdy, 1980; Fox et al., 1980), but in other respects Hole $735 \mathrm{~B}$ appears to have sampled "normal" ocean crust.

\section{Lithostratigraphy}

A total of $435 \mathrm{~m}$ of gabbro, olivine gabbro, $\mathrm{Fe}$-Ti oxide gabbro, and gabbronorite was recovered from this hole. The sequence was originally divided into six major lithologic units by the shipboard scientific party (Robinson, Von Herzen, et al., 1989), each distinguished by differences in texture and mineralogy. Following a complete redescription of the core, 
Table 1. Lithostratigraphy of Hole 735B.

\begin{tabular}{|c|c|c|c|}
\hline $\begin{array}{l}\text { Lithologic } \\
\text { unit }\end{array}$ & Depth (mbsf) & $\begin{array}{l}\text { Core, section, } \\
\text { interval }(\mathrm{cm})\end{array}$ & Lithology \\
\hline IA & $0-27.99$ & $\begin{array}{l}\text { 1D-1, } 0 \\
7 \mathrm{D}-1,114\end{array}$ & Deformed gabbronorite. \\
\hline IB & $27.99-37.41$ & $\begin{array}{l}7 \mathrm{D}-1,114 \\
10 \mathrm{D}-1,70\end{array}$ & $\begin{array}{l}\text { Mixed gabbronorite and } \\
\text { olivine gabbro. }\end{array}$ \\
\hline II & $37.41-170.22$ & $\begin{array}{l}10 \mathrm{D}-1,70 \\
35 \mathrm{R}-6,72\end{array}$ & $\begin{array}{l}\text { Olivine gabbro with } \\
\text { intervals of Fe-Ti oxide } \\
\text { gabbro. }\end{array}$ \\
\hline IIIA & $170.22-180.09$ & $\begin{array}{l}35 \mathrm{R}-6,72 \\
37 \mathrm{R}-3,70\end{array}$ & $\begin{array}{l}\text { Disseminated } \mathrm{Fe}-\mathrm{Ti} \text { oxide } \\
\text { gabbro and olivine } \\
\text { gabbro with intervals of } \\
\text { oxide gabbro. }\end{array}$ \\
\hline IIIB & $180.09-209.45$ & $\begin{array}{l}37 \mathrm{R}-3,70 \\
43 \mathrm{R}-3,98\end{array}$ & $\begin{array}{l}\text { Disseminated } \mathrm{Fe}-\mathrm{Ti} \text { oxide } \\
\text { olivine gabbro with } \\
\text { intervals of } \mathrm{Fe}-\mathrm{Ti} \text { oxide } \\
\text { gabbro and rare olivine } \\
\text { gabbro. }\end{array}$ \\
\hline IIIC & $209.45-223.57$ & $\begin{array}{l}43 \mathrm{R}-3,98 \\
46 \mathrm{R}-2,150\end{array}$ & $\begin{array}{l}\text { Mixed disseminated } \mathrm{Fe}-\mathrm{Ti} \\
\text { oxide olivine gabbro and } \\
\text { Fe-Ti oxide gabbro. }\end{array}$ \\
\hline IV & $223.57-274.06$ & $\begin{array}{l}46 \mathrm{R}-2,150 \\
56 \mathrm{R}-3,116\end{array}$ & $\begin{array}{l}\text { Massive Fe-Ti oxide } \\
\text { gabbro. }\end{array}$ \\
\hline V & $274.06-382.40$ & $\begin{array}{l}56 \mathrm{R}-3,116 \\
74 \mathrm{R}-6,3\end{array}$ & Isotropic olivine gabbro. \\
\hline VIA & $382.40-404.01$ & $\begin{array}{l}74 \mathrm{R}-6,3 \\
77 \mathrm{R}-1,53\end{array}$ & Compound olivine gabbro. \\
\hline VIB & $404.01-419.28$ & $\begin{array}{l}77 \mathrm{R}-1,53 \\
79 \mathrm{R}-4,56\end{array}$ & $\begin{array}{l}\text { Mixed olivine and } \mathrm{Fe}-\mathrm{Ti} \\
\text { oxide-olivine gabbro. }\end{array}$ \\
\hline VIC & $419.28-433.77$ & $\begin{array}{l}79 \mathrm{R}-4,56 \\
81 \mathrm{R}-1,26\end{array}$ & $\begin{array}{l}\text { Compound olivine gabbro } \\
\text { and troctolite. }\end{array}$ \\
\hline VID & $433.77-500.70$ & $\begin{array}{l}81 \mathrm{R}-1,26 \\
88 \mathrm{R}-1,70\end{array}$ & $\begin{array}{l}\text { Compound olivine and } \\
\text { Fe-Ti oxide-olivine } \\
\text { gabbro. }\end{array}$ \\
\hline
\end{tabular}

the locations of some unit boundaries have been shifted, and several units have been subdivided further (Table 1) (Dick et al., this volume).

\section{Mineralogy and Petrography}

\section{Unit I}

Unit I consists of $37.5 \mathrm{~m}$ of mostly deformed gabbronorite and minor olivine gabbro. Two subdivisions are recognized; an upper sequence, $28 \mathrm{~m}$ thick, of highly deformed gabbronorite and a lower 15.5-m-thick section of less deformed gabbro and olivine gabbro.

The foliated metagabbronorites have well-developed porphyroclastic to mylonitic textures, and in general, primary igneous textures have been completely obliterated. Foliation is well developed and is defined largely by alternating layers of plagioclase and amphibole or pyroxene. Rounded and deformed porphyroclasts consist mostly of plagioclase, clinopyroxene, and rare orthopyroxene and are set in a matrix of minute neoblasts of the same minerals. In most specimens, brown or green amphibole partly to completely replaces the pyroxene, and in some highly metamorphosed metagabbros, amphibole is the only mafic phase preserved. A few mylonitic bands are rich in Fe-Ti oxides, which typically fill fractures and pore spaces in the rock. Small veins of green or brown amphibole and sodic plagioclase commonly crosscut the foliation. Red-brown pseudomorphs of olivine and orthopyroxene are present in many specimens.

\section{Unit II}

Unit II consists of $132.7 \mathrm{~m}$ of largely olivine gabbro and gabbronorite, with a few intervals of oxide gabbro. Most of the rocks in Unit II are mesocumulates having anhedral to subhedral granular textures, and grain size layering is commonly present.
Olivine averages less than $5 \%$ by volume and is mostly replaced by colorless amphibole, talc, secondary magnetite, and some brown clay minerals. Clinopyroxene forms anhedral to subhedral grains generally less than $5 \mathrm{~mm}$ wide, but in a few specimens, it occurs as large oikocrysts enclosing plagioclase. Orthopyroxene forms up to $5 \%$ by volume and is generally most abundant in the upper parts of the unit. Both clinopyroxene and orthopyroxene have been extensively replaced by green and brown amphibole.

A few layers or bands of Fe-Ti oxide gabbro consist chiefly of plagioclase and clinopyroxene, with minor inverted pigeonite. The oxides are intimately intergrown with the pyroxenes and are commonly associated with sulfides. In most cases, the oxide-rich layers are associated with small shear zones in which secondary amphibole is abundant. Outside of these zones, the rocks are little deformed and have undergone only static alteration in which olivine has been replaced by magnesian amphiboles, talc, and oxides; pyroxene is rimmed with green amphibole.

\section{Unit III}

Unit III is a 53.4-m-thick section composed chiefly of olivine gabbro having variable proportions of Fe-Ti oxides. At the top is an interval of Fe-Ti oxide gabbro, $10.8 \mathrm{~m}$ thick, (Unit IIIA) composed of plagioclase and clinopyroxene \pm inverted pigeonite and $\mathrm{Fe}$-Ti oxides. Unit IIIB consists of 28.4 $\mathrm{m}$ of disseminated oxide olivine gabbro characterized by about $1 \% \mathrm{Fe}$-Ti oxides, whereas Unit IIIC consists chiefly of olivine gabbro having minor disseminated $\mathrm{Fe}-\mathrm{Ti}$ oxides. Shearing and mylonitization are less common in Unit III than in the overlying units, but a few deformed zones are present in Cores 118-735A-38R and -39R.

Most of the rocks in Unit III are coarse- to very coarsegrained gabbros with mesocumulate textures. These are composed chiefly of plagioclase and clinopyroxene, with little olivine and minor amounts of disseminated Fe-Ti oxides. A few zones have $5 \%$ to $10 \%$ olivine, and small amounts $(1 \%-2 \%)$ of inverted pigeonite are commonly present. Fe-Ti oxides average about 1 modal percent, but in a few layers may constitute up to $5 \%$. These Fe-Ti oxide-rich bands or layers typically coincide with small shear zones in which the rocks have porphyroclastic to mylonitic textures.

The rocks of Unit III are relatively fresh, but olivine typically has been replaced by tremolite and talc, and pyroxenes are rimmed by green amphibole. Small veins in sheared zones contain assemblages of sodic plagioclase $\left(\mathrm{An}_{10-20}\right)$, hornblende, sphene, and some chlorite.

\section{Unit IV}

Unit IV is a 50.5 -m-thick sequence of massive Fe-Ti oxide gabbro. The rocks of this unit are significantly richer in $\mathrm{Fe}-\mathrm{Ti}$ oxides than either the overlying disseminated oxide gabbros or the underlying olivine gabbros.

The gabbros of Unit IV have more evolved compositions than the overlying and underlying rocks. Olivine rarely exceeds 2 modal percent and is commonly absent. Where present, it typically has an iron-rich composition $\left(\mathrm{Fo}_{35-45}\right)$. Plagioclase feldspar is relatively sodic, with compositions as low as $\mathrm{An}_{30}$. Both augite and inverted pigeonite are present.

The textures of the oxide gabbros are variable. Undeformed rocks have coarse-grained mesocumulate textures, and the oxide occurrences in these rocks appear to be primary. The Fe-Ti oxides are post-cumulus or late magmatic phases that fill spaces between plagioclase and pyroxene grains, and in some cases, poikilitically enclose the silicate minerals. In more deformed specimens having porphyroclastic to submylonitic textures, the Fe-Ti oxides show much greater evidence of mobility. Cracks and small shear 
zones are filled with ilmenite, which appears to be secondary, and with variable assemblages of green amphibole, epidote, sphene, and in some cases, chlorite. In these rocks, the ilmenite clearly has been mobilized during deformation.

A few layers of olivine gabbro, 20 to $100 \mathrm{~cm}$ thick, also are present in Unit IV. These are texturally similar to the undeformed gabbros, but have higher modal percentages of olivine and more primitive mineral compositions.

\section{Unit $V$}

A relatively uniform sequence of isotropic olivine gabbro, about $108 \mathrm{~m}$ thick, makes up Unit V. Compared to the upper part of the sequence in Hole 735B, the rocks of Unit $\mathrm{V}$ have been little deformed. The rocks are characterized by the nearly ubiquitous presence of olivine and the lack of both Fe-Ti oxides and inverted pigeonite. Typical specimens have coarse-grained mesocumulate textures and consist of about $45 \%$ to $55 \%$ plagioclase, $40 \%$ to $45 \%$ clinopyroxene, $5 \%$ to $10 \%$ olivine, and traces of orthopyroxene. A troctolite layer in Section 118-735B-63R-4 contains abundant olivine and little or no clinopyroxene. Some primary layering is present and is defined chiefly by grain size variations or, rarely, by lamination of the plagioclase grains. Mineral compositions are relatively uniform with olivine averaging about $\mathrm{Fo}_{75-80}$ and plagioclase mostly between $\mathrm{An}_{60-65}$. $\mathrm{An} \mathrm{Fe}-\mathrm{Ti}$ oxide-rich layer occurs in Sample 118-735B-73R-4, $81-86 \mathrm{~cm}$, where it is associated with a small shear zone.

The rocks of Unit V are relatively fresh, but numerous felsic veins are associated with narrow zones of brecciation. These veins typically contain varying assemblages of diopside, green amphibole, sodic plagioclase, epidote, and sometimes, chlorite.

\section{Unit VI}

Unit VI is a heterogeneous sequence of isotropic olivine gabbro having layers of troctolite and ferrogabbro. The unit extends from $371.87 \mathrm{~m}$ to the base of the hole and is at least $129 \mathrm{~m}$ thick. Most of the unit consists of coarse-grained olivine gabbro ( $>10 \%$ olivine), some of which has cumulate textures. Layers of troctolite and olivine microgabbro are common, and many of these appear to be intrusive bodies, either dikes or sills concordant to the original layering. Layering in Unit VI is defined chiefly by grain size variations, but phase layering is also present. A few sheared zones are rich in $\mathrm{Fe}$ - $\mathrm{Ti}$ oxides.

The rocks consist of variable proportions of olivine, plagioclase, and pyroxene, with minor spinel. Olivine typically exceeds 10 modal percent and can be up to 50 or 60 modal percent in the troctolites. Fresh olivine grains generally have compositions between $\mathrm{Fo}_{65-85}$, but those in the ferrogabbros are more iron-rich. Plagioclase crystals are euhedral to subhedral and commonly up to $1 \mathrm{~cm}$ long. Plagioclase averages about $\mathrm{An}_{65}$, but it varies from about $\mathrm{An}_{30}$ in some ferrogabbros to $\mathrm{An}_{75}$ in some troctolites. Clinopyroxene commonly forms large, subhedral oikocrysts enclosing plagioclase.

Alteration in Unit VI has been mostly restricted to small veins, commonly associated with shear zones that contain mixtures of diopside, epidote, sodic plagioclase, green amphibole, and chlorite. Some large olivine crystals have been replaced by reddish-brown Fe oxides.

\section{STYLES OF ALTERATION}

Five major styles of alteration or metamorphism are present in the rocks of Hole 735B (Table 2). These are, from early to late: (1) high-temperature metamorphism associated with brittle-ductile deformation; (2) static alteration during which olivine and some orthopyroxene were partly to completely replaced by Fe-Mg amphiboles, talc, and secondary magnetite; (3) infilling of inclined veins formed during brittle deformation; (4) deposition of green smectite in subvertical cracks; and (5) late-stage replacement of olivine and some pyroxene grains by reddish Fe-oxides, carbonate, and clay minerals. The inferred age relationships are based on textural data and estimated temperatures of formation of the secondary minerals involved.

\section{High-Temperature Metamorphism}

Two types of brittle-ductile deformation can be recognized in the rocks of Hole 735B: a late magmatic stage associated with formation of the oxide gabbros and a subsolidus stage associated with granulite and amphibolite facies metamorphism (Cannat et al., this volume; Stakes et al., this volume; Dick et al., this volume). The late magmatic deformation is concentrated in lithologic Units III and IV, where Fe-Ti oxide gabbros are abundant, but also occurs locally in Unit I, where it is overprinted by later subsolidus deformation. Subsolidus deformation is most common in the upper parts of the core, where the rocks have well-developed porphyroclastic and mylonitic textures (Cannat et al., this volume).

Here, we are concerned only with the subsolidus deformation and associated granulite to amphibolite facies metamorphism. Subsolidus deformation has been best preserved in Unit I but is also present in Unit II and in thin shear zones that occur throughout the core, except for an interval extending from the top of Unit IV $(223.57 \mathrm{~m})$ to the base of Unit VIB $(419.28 \mathrm{~m})$ (Dick et al., this volume).

Two major mineral assemblages have been recognized in these rocks, one formed at low water/rock ratios, the other at high water/rock ratios, although there are various gradations between them (Cannat et al., this volume; Stakes et al., this volume). The assemblage formed at low water/rock ratios consists chiefly of igneous minerals that have been partially to completely recrystallized and re-equilibrated to somewhat lower P-T conditions. These rocks consist chiefly of plagioclase, clinopyroxene, and orthopyroxene, but also contain rare olivine, brown amphibole, and $\mathrm{Fe}$-Ti oxides. Variations in mineral assemblages largely reflect the compositions of the protoliths (chiefly gabbronorite in Unit I and olivine gabbro in Unit II). Ovoid porphyroclasts of igneous minerals are surrounded by neoblasts of plagioclase, pyroxene, olivine, and brown amphibole. Most neoblasts are compositionally similar to adjacent porphyroclasts, although plagioclase may be slightly more sodic and clinopyroxene slightly more diopsidic. Orthopyroxene typically occurs as small crushed grains around porphyroclasts, rather than as neoblasts. Red-brown hornblende forms small blebs within clinopyroxene porphyroclasts and also occurs as small polygonal neoblasts (Stakes et al., this volume).

With increasing water/rock ratios, pyroxene has been progressively replaced by amphibole, forming an amphibolite gneiss (Pl. 1, Figs. 1 and 2). Typical mineral assemblages in these rocks include plagioclase, $\mathrm{Fe}$-Ti oxide, green and brown amphibole, and some brown mica. Some samples contain relict porphyroclasts of pyroxene (PI. 1, Fig. 3), but in most cases, these have also been replaced by amphibole. These amphibole gneisses are texturally and mineralogically similar to dredged samples from the Vema Fracture Zone (Honnorez et al., 1984) and the MidCayman Rise (Ito and Anderson, 1983). Many of these foliated rocks also contain amphibole veins that crosscut or are cut by the foliation (Pl. 2, Fig. 2). The vein amphibole is similar in composition to that defining the foliation, and both are aluminous magnesio-hornblende. Some of the aluminous magnesiohornblendes contain significant amounts of chlorine ( $\mathrm{a}$ few tens of a percent up to $1.5 \mathrm{wt} \%$ ) (Vanko and Stakes, this volume), suggesting formation by seawater/rock interaction (Ito and Anderson, 1983; Batiza and Vanko, 1985; Vanko, 1986; Mével, 
Table 2. Styles of alteration in Hole 735B.

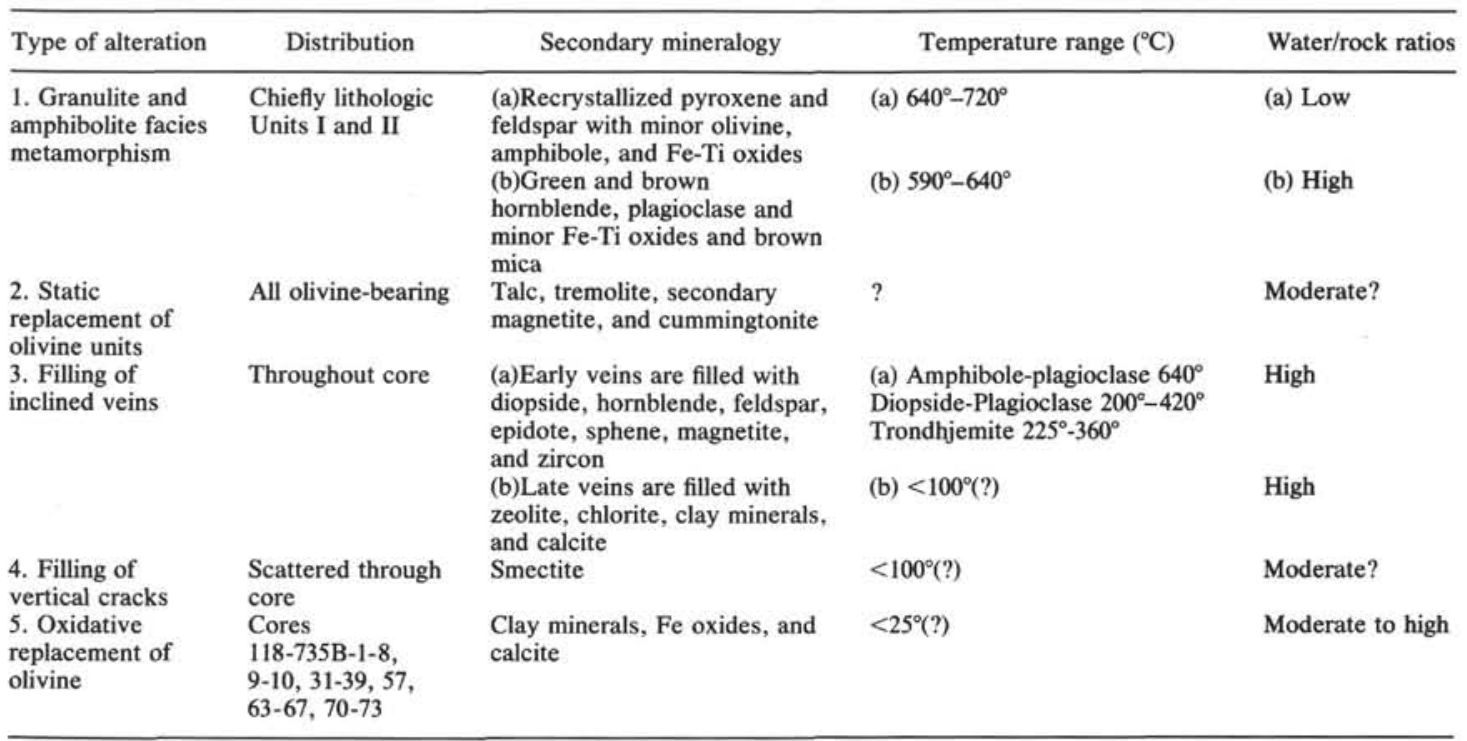

1988). Iron-rich hornblendes are relatively rare, and occur only in the trondhjemitic patches.

A few amphibolite gneisses also contain small amounts of actinolitic hornblende and intermediate to sodic plagioclase. The actinolitic hornblende commonly replaces porphyroclasts or rims previously formed magnesio-hornblende. Stakes et al. (this volume) interpret this assemblage as marking the terminal stage of hydrous ductile deformation.

The earliest stage of ductile deformation and anhydrous metamorphism, marked by recrystallization of orthopyroxene, may have occurred within the granulite facies. Augite porphyroclasts in these rocks still have magmatic oxygen isotopic compositions, with ${ }^{18} \mathrm{O}$ values of between 5.08 and 5.4 $\%$ (Vanko and Stakes, this volume), indicating that little or no reaction with seawater has occurred. This is consistent with the low water/rock ratios in these rocks. However, as water penetrated into the system, water/rock ratios increased and the temperatures of metamorphism decreased to amphibolite grade. Actinolitic hornblende and actinolite in these rocks have ${ }^{18} \mathrm{O}$ values as low as $1.6 \%$, and much of the plagioclase also is isotopically depleted, indicating considerable exchange with seawater (Vanko and Stakes, this volume). Estimated temperatures of the amphibolite grade metamorphism (based on mineral compositional data) range from about $590^{\circ}$ to $720^{\circ} \mathrm{C}$ and cluster around $640^{\circ} \mathrm{C}$ (Vanko and Stakes, this volume). Hornblende-plagioclase veins in these rocks yield temperatures of about $640^{\circ} \mathrm{C}$, whereas later-stage alteration associated with the brecciated horizons took place at temperatures of less than $500^{\circ} \mathrm{C}$ (Vanko and Stakes, this volume).

\section{Static Alteration}

Static alteration under hydrous conditions occurred extensively throughout the core, but is most common and best developed in the undeformed zones. Partial to complete replacement of olivine and, rarely, orthopyroxene is the most widespread and obvious static alteration in the core. Most olivine grains exhibit at least some marginal alteration, chiefly to colorless amphibole, talc, and secondary magnetite. In other cases, the primary minerals have been completely pseudomorphed by secondary minerals (Pl. 2, Figs. 1 and 2). Tremolite is the most common amphibole in the pseudomorphs, although cummingtonite and anthophyllite have also been identified. The amphiboles commonly form networks of randomly oriented, tabular grains, or they may form bands of oriented grains that are either parallel or perpendicular to the original boundary of the primary crystal. In the latter case, the olivine pseudomorphs are commonly zoned, with mixtures of tremolite and talc in the cores and bands of tremolite, cummingtonite, or anthophyllite on the rim. The secondary magnetite occurs in minute grains, commonly arranged in concentric bands parallel to the outline of the original crystal.

Other types of static alteration also are locally present, but are volumetrically insignificant. Small amounts of pargasitic amphibole and phlogopite occur along some olivine-plagioclase grain boundaries, and minute amounts of clinozoisite locally replace feldspar grains. In some amphibole gneisses, plagioclase is rimmed by actinolite and minor chlorite, and clinopyroxene porphyroclasts may be partly replaced by actinolite or actinolitic hornblende (Stakes et al., this volume).

Neither the origin nor the timing of the static alteration is clear. Because it largely affects olivine and, to a lesser extent, orthopyroxene, its distribution is related to variations in primary mineralogy. In general, the distribution of this type of alteration does not reflect vein density or the proximity to specific veins. Thus, it may be in part deuteric, i.e., olivine and orthopyroxene may have reacted with late-stage magmatic fluids at relatively high temperatures. Alternatively, it may mark an influx of seawater into the cooling rocks along minute cracks and grain boundaries. Where pyroxene porphyroclasts have been pseudomorphed by actinolite or actinolitic hornblende in the ductilely deformed zones, the amphibole has ${ }^{18} \mathrm{O}$ values as low as $1.6 \%$, clearly indicating the influx of seawater (Vanko and Stakes, this volume). However, these highly deformed zones acted as conduits for the influx of seawater, whereas no such obvious channelways exist in the undeformed rocks.

The static alteration may have been penecontemporaneous with or slightly later than the brittle-ductile deformation and amphibolite facies metamorphism. It is best preserved in the undeformed zones, but some olivine pseudomorphs are present in the foliated rocks. Where these occur, the pseudomorphs are elongated parallel to the foliation, but the individual secondary minerals are not. This suggests that the pseudomorphs formed by static alteration of deformed olivine grains after deformation ceased. If earlier static alteration occurred it was overprinted by the amphibolite-facies metamorphism. 


\section{Filling of Inclined Veins}

Both hydrothermal and late magmatic veins are abundant in Hole $735 \mathrm{~B}$, and together they make up about $2.4 \%$ of the core (Dick et al., this volume). These are inclined veins having a mean dip of about $60^{\circ}$. They are distinguished from later subvertical fractures on the basis of dip and secondary mineral assemblages. The later fractures have a mean dip of about $70^{\circ}$ and commonly cut the inclined veins. The late fractures are filled solely with green smectite, whereas the inclined veins have highly variable mineral assemblages. The inclined veins occur throughout the core, except in the highly brecciated zone at the base of Unit IV. Overall, these veins are distributed rather uniformly down the hole; however, there are several different types of veins, and each type has its own unique distribution. The most common vein assemblages are (Dick et al., this volume) as follows:

$\begin{array}{lc}\text { Amphibole } & 32 \% \\ \text { Felsic } & 26 \% \\ \text { Trondhjemite } & 18 \% \\ \text { Plagioclase+diopside } & 12 \% \\ \text { Plagioclase+amphibole } & 7 \% \\ \text { Other } & 5 \%\end{array}$

However, such a tabulation is somewhat misleading because many veins exhibit sequential assemblages, reflecting deposition of successively lower temperature minerals as the hydrothermal fluids cooled down. This is particularly true of the plagioclasediopside and felsic veins, many of which are strongly zoned and some of which contain narrow bands of zeolite, carbonate, or clay minerals in their centers (Pl. 4, Figs. 1 and 2).

\section{Amphibole Veins}

Nearly one-third of all veins in Hole 735B are monomineralic amphibole veins. These are typically restricted to the zones of brittle-ductile deformation and associated amphibolite facies metamorphism and thus are most abundant in the upper $150 \mathrm{~m}$ of the core. The amphibole veins take several different forms and are both cut by and cut the gneissic and mylonitic foliations in these rocks (Pl. 1, Fig. 2). In the zones of most intense deformation, particularly in the upper $40 \mathrm{~m}$ of the core, the veins generally do not cut the foliation. If early cross-cutting veins existed, they apparently have been rotated into the plane of foliation. In the less deformed rocks, amphibole veins typically form long narrow cracks, 1 to $3 \mathrm{~mm}$ wide, that are oriented perpendicular to the foliation. Also present are microcracks in porphyroblasts and more continuous cracks that extend through both porphyroblasts and bands of neoblasts.

The monomineralic amphibole veins typically are filled with green or greenish-brown magnesio-hornblende. The amphibole crystals may be oriented perpendicular to the vein walls, producing a cross-fiber texture, or they may be parallel. Some relatively large euhedral crystals are compositionally zoned. As pointed out earlier, however, there is little difference in composition between hornblende that replaces primary phases and that which fills veins.

The close association of hornblende veins and brittleductile deformation suggests that these veins are closely related to the amphibolite facies metamorphism. Because the veins both crosscut and are cut by the foliation in these rocks, vein formation must have overlapped with and extended somewhat beyond the period of deformation. This interpretation is supported by the overlap in estimated temperatures of formation for metamorphic amphibole $\left(590^{\circ}\right.$ to $\left.720^{\circ} \mathrm{C}\right)$ and vein hornblende (about $640^{\circ} \mathrm{C}$ ) (Vanko and Stakes, this volume).
In addition to the monomineralic varieties, numerous amphibole-bearing veins occur in the lower parts of the core (Pl. 3 , Fig. 1), but in these the amphibole is relatively minor and typically rims other minerals, such as diopside.

\section{Trondhjemite Veins}

Trondhjemite veins make up about one-fifth of the total veins and occur most abundantly in the Fe-Ti oxide gabbros. They typically are 1 to $2 \mathrm{~cm}$ wide and occur in discrete zones (Dick et al., this volume). Locally, these veins were deformed during subsolidus brittle-ductile deformation. Deformation is particularly striking in the amphibolite gneisses in the upper $100 \mathrm{~m}$ of the core, where early veins have been transposed into the plane of foliation. Where this has occurred, the transposed veins are difficult to distinguish from other felsic layers.

Most of the trondhjemites have igneous textures characterized by euhedral plagioclase grains. Typical mineral assemblages are sodic plagioclase, quartz, minor brown amphibole or biotite, and trace amounts of zircon, all of which are compatible with an igneous origin. However, many of these veins appear to have been modified by hydrothermal fluids and in these cases their origin is ambiguous.

The trondhjemite liquids are thought to have formed as highly evolved late-magmatic fluids that impregnated the Fe-Ti oxide gabbros (Dick et al., this volume). However, homogenization temperatures of fluid inclusions in quartz from these rocks range from about $227^{\circ}$ to $358^{\circ} \mathrm{C}$, and those for inclusions in plagioclase cluster around $270^{\circ} \mathrm{C}$. (Vanko and Stakes, this volume). These temperatures indicate formation of the quartz and feldspar either from hydrothermal fluids or from magmatic fluids that had undergone significant cooling.

\section{Felsic Veins}

Of even more problematic origin is a suite of felsic veins having variable mineral assemblages, including such minerals as sodic plagioclase, diopside, amphibole, epidote, sphene, magnetite, and zircon. Some of these are essentially monomineralic veins ( $\mathrm{Pl}$. 4, Fig. 3), but most are compound, with obviously zoned assemblages. A typical zoned vein has relatively large diopside crystals along the margins, followed by tabular crystals of epidote (PI. 3, Fig. 4), in turn followed by aggregates of small anhedral feldspar grains that make up the central part. Some diopside crystals are euhedral and show strong zoning of iron and magnesium (Pl. 3, Fig. 2); others are barrel-shaped or anhedral and relatively uniform in composition. Many diopside crystals are rimmed with green actinolite, and actinolite may occur on the vein walls, where the veins cut primary pyroxene grains in the host rocks (Pl. 3, Fig. 1). Scattered crystals of sphene, ilmenite, pyrite, allanite, and biotite are commonly present in the central parts of the veins (e.g., Pl. 1, Fig. 4). Pale green, brown, or colorless chlorite also is locally present and appears either to replace plagioclase or to fill irregular cavities in the veins (Pl. 3, Fig. 3 and Pl. 4, Fig. 4).

These veins probably formed chiefly by sequential growth of secondary minerals inward from the walls of fractures. However, some replacement of the primary minerals, particularly augite by hornblende, is suggested by the textural relationships (PI. 3, Fig. 1).

Fluid inclusions in vein diopsides homogenize at temperatures ranging from $313^{\circ}$ to $420^{\circ} \mathrm{C}$, but most do so at between about $370^{\circ}$ and $400^{\circ} \mathrm{C}$ (Vanko and Stakes, this volume). Inclusions in vein plagioclase from the same specimens are slightly less saline than those in diopside and homogenize at distinctly lower temperatures, generally between $207^{\circ}$ and $285^{\circ} \mathrm{C}$ (Vanko and Stakes, this volume). 
Many of these veins also contain low-temperature secondary minerals, such as zeolites, clay minerals, or carbonates (PI. 4, Figs. 1, 2, and 4). In some case, these minerals occur as irregular patches and appear to replace preexisting minerals, particularly feldspar; in others, the earlier veins have reopened, and lowtemperature minerals fill cracks cutting through the highertemperature assemblages (PI. 4, Figs. 1 and 2).

Some of the felsic veins have textures, particularly euhedral plagioclase crystals, similar to those of the trondhjemites, suggesting a possible magmatic origin. Stakes et al. (this volume) argue that many of these veins represent late magmatic liquids, particularly if they contain quartz and zircon. In this model, the veins represent magmatic materials, some of which were later modified by hydrothermal fluids to produce such minerals as epidote and chlorite. Vanko and Stakes (this volume) found that the oxygen isotope characteristics of most felsic veins reflect a strong hydrothermal influence. Only zircon-bearing veins have near-magmatic isotopic compositions, whereas others have $\delta^{18} \mathrm{O}$ values that suggest formation from seawater.

As pointed out by Stakes et al. (this volume), there appears to be a complete gradation from clearly trondhjemitic veins to clearly hydrothermal veins, and early magmatic veins may well have been modified by later hydrothermal processes. However, we suggest that only those felsic veins containing quartz and/or zircon are likely to have formed from late magmatic fluids. Most, if not all, of the diopside-bearing veins have textures, mineralogies, and isotopic compositions that suggest a hydrothermal origin. Such an interpretation is greatly strengthened by the fluid inclusion data from vein diopsides, which suggest temperatures of formation of about $550^{\circ} \mathrm{C}$ (Vanko and Stakes, this volume).

\section{Smectite-Lined Fracture}

A series of late-stage, subvertical, clay-lined fractures clearly post-date the earlier veins. These differ from the earlier veins in that they are narrow, irregular features that break around mineral grains, rather than through them. These veinlets have a mean dip of about $70^{\circ}$ and crosscut the inclined veins. Most of these are discontinuous and rarely extend for more than $1 \mathrm{~m}$ along the core axis (Dick et al., this volume). They are generally absent in the highly deformed gneissic intervals and occur most commonly in the coarsely crystalline undeformed rocks near the base of the hole. They probably reflect release of stored elastic thermal strain during unloading of the section, perhaps by erosion to sea level after uplift (Dick et al., this volume).

Green smectite is the only mineral in these late-stage fractures, suggesting formation at temperatures less than about $50^{\circ} \mathrm{C}$ (cf. Kristmannsdottir, 1979).

\section{Late-Stage Oxidation}

The last recognizable stage of alteration involves oxidation of olivine and, locally, orthopyroxene. In hand specimen, this alteration is easily recognizable by the presence of red to reddish-brown clots in an otherwise light gray to light brown rock. The altered zones occur in definite intervals within the core, and their distribution presumably reflects access of oxygenated seawater along cracks or fractures. The major zones of alteration occur in Cores 118-735B-1D-8D, -9D through $-10 R,-37 R$ through $-39 R,-57 R,-63 R$ through $-67 R$, and $-70 \mathrm{R}$ through $-73 \mathrm{R}$. However, the degree of alteration varies considerably within these intervals, and the most intense alteration typically is concentrated along relatively narrow bands.

In thin section, altered pyroxene grains are reddened and partly replaced by $\mathrm{Fe}$ oxides and clay minerals, but the original mineral is still readily identifiable. On the other hand, olivine is commonly completely pseudomorphed by the secondary minerals, resulting in opaque clots (PI. 2, Figs. 3 and 4). Where the olivine grains have been partly replaced during the earlier static alteration, the opaque clots are rimmed by coronas of talc, tremolite, and secondary magnetite (Pl. 2, Fig. 4). In a few cases, olivine has been replaced by green brown clay minerals (smectite) or calcite, as well as ferric oxides. Calcite veinlets are common in many of the oxidized zones, and these presumably acted as the channelways along which seawater penetrated the rock. In many cases, these veinlets formed by reopening of earlier felsic veins (Pl. 4, Fig. 2). Most of this alteration probably took place at temperatures near those of ambient seawater.

\section{CHEMICAL EFFECTS OF ALTERATION}

Although no systematic studies of the chemical effects of alteration in Hole 735B have been conducted, one can draw some conclusions from the shipboard geochemical data (Robinson, Von Herzen, et al., 1989). Figure 1 depicts downhole variations in the common alteration-sensitive oxides: $\mathrm{Fe}_{2} \mathrm{O}_{3}$, $\mathrm{H}_{2} \mathrm{O}, \mathrm{CO}_{2}$, and $\mathrm{K}_{2} \mathrm{O}$. A significant increase in $\mathrm{H}_{2} \mathrm{O}$ is apparent in the upper parts of the core in lithologic Units I and II. Although variable, water contents of these rocks range up to $2.4 \mathrm{wt} \%$, which is significantly above the average background value of about $0.5 \mathrm{wt} \%$.

The hydration of these rocks reflects an influx of water during brittle-ductile deformation and amphibolite facies metamorphism. Relatively high chlorine contents in some amphiboles indicates formation from seawater-derived fluids.

Lower in the core, below about $180 \mathrm{~m}$, deformation is limited, and the rocks are significantly less hydrated. The highest recorded water content in this part of the core is about $1.4 \mathrm{wt} \%$, and such values occur only in narrow shear zones, which apparently acted as conduits for water flow. Some hydration is recorded in the veins, which contain such minerals as amphibole, epidote, chlorite, zeolite, and clay minerals, but the veins make up only about $2.5 \%$ of the entire core. Thus, their influence on bulk rock compositions is limited.

$\mathrm{CO}_{2}$ and $\mathrm{K}_{2} \mathrm{O}$ contents also are considerably elevated above background levels in the upper $150 \mathrm{~m}$ of core. Background levels of $\mathrm{CO}_{2}$ are less than $0.1 \mathrm{wt} \%$, and maximum values range up to $0.35 \mathrm{wt} \% . \mathrm{K}_{2} \mathrm{O}$ exhibits a small but steady decrease downhole, from an average of about $0.08 \mathrm{wt} \%$ at the top to about $0.04 \mathrm{wt} \%$ at the base. Higher values (up to 0.36 wt\%) occur in the upper, hydrated section and locally in the lower parts of the core. The relatively high $\mathrm{CO}_{2}$ and $\mathrm{K}_{2} \mathrm{O}$ contents in the upper parts of the core reflect seawater/rock interaction, probably after the section was exposed onto the seafloor. $\mathrm{FeO}_{\mathrm{x}}$ ratios range from a low of about 0.05 to a high of about 0.46 . The highest values occur in Unit IV, the sequence of Fe-Ti oxide gabbro. Because the rocks of this interval are not hydrated and only locally enriched in $\mathrm{CO}_{2}$ or $\mathrm{K}_{2} \mathrm{O}$, the high ferric/total iron ratios probably reflect original magmatic conditions. On the other hand, the elevated ratios that occur in the upper part of the core, and locally in the lower part, appear to reflect the late-stage oxidative alteration discussed above. In these cases, oxygenated seawater reacted with olivine and orthopyroxene to form pseudomorphs of ferric oxides, clay minerals, and carbonates.

It is interesting to note that although the rocks of lithologic Unit $\mathrm{I}$ are enriched in $\mathrm{H}_{2} \mathrm{O}, \mathrm{CO}_{2}, \mathrm{~K}_{2} \mathrm{O}$, and ferric oxides, individual samples show wide variations in these alteration indexes. As previously noted for seafloor basalts (e.g., Robinson et al., 1977), the alteration sensitive oxides do not necessarily vary sympathetically, but rather follow different trends. Rocks may be very hydrated, but show little, if any, 


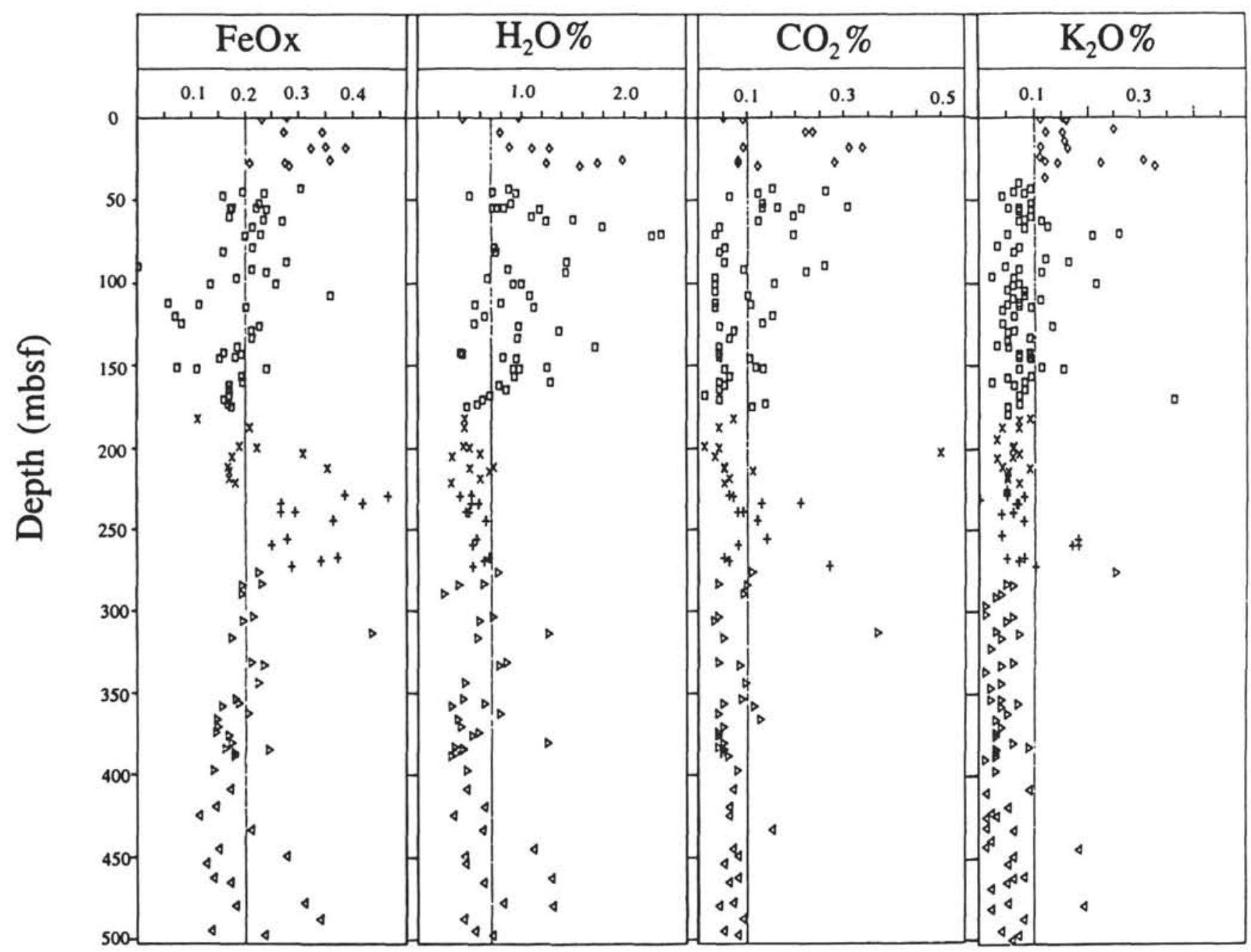

Figure 1. Downhole variations in $\mathrm{FeO}_{\mathrm{x}}$ (ferric oxide divided by total iron expressed as $\mathrm{Fe}_{2} \mathrm{O}_{3}$ ), $\mathrm{H}_{2} \mathrm{O}, \mathrm{CO}_{2}$, and $\mathrm{K}_{2} \mathrm{O}$ in $\mathrm{Hole} 735 \mathrm{~B}$. $\diamond=$ lithologic Unit I, $\square=$ Unit II, $\times=$ Unit III, $+=$ Unit IV, $\triangleright=$ Unit V, and $\triangleleft=$ Unit VI. Data are from Robinson, Von Herzen, et al. (1989) and R. Emmermann and P. Robinson (unpubl. data).

enrichment in $\mathrm{CO}_{2}, \mathrm{~K}_{2} \mathrm{O}$, or ferric oxide. Conversely, enrichment in $\mathrm{CO}_{2}, \mathrm{~K}_{2} \mathrm{O}$, and ferric oxide can occur without significant hydration. This confirms that alteration in these rocks is not pervasive and that many microdomains are present, each characterized by fluids of specific composition.

\section{DYNAMIC MODEL FOR ALTERATION OF LAYER 3}

The gabbros of Hole 735B are thought to have formed in a magma chamber beneath the Southwest Indian Ridge at about $12 \mathrm{Ma}$ (Robinson, Von Herzen, et al., 1989). The size, shape, and longevity of the chamber are not known, but there is no evidence in the core to suggest the presence of a large, continuously evolving chamber.

As the rocks of Hole 735B crystallized and cooled, they underwent at least two stages of high-temperature, brittle-ductile deformation. A late magmatic stage was associated with intrusion of Fe-Ti-rich magma to form the oxide gabbros of lithologic Units III and IV. A later stage of subsolidus deformation, particularly well developed in lithologic Unit I, produced strongly foliated rocks having porphyroclastic and mylonitic textures. Where temperatures were high $\left(650^{\circ}-750^{\circ} \mathrm{C}\right)$ and water/ rock ratios low, the primary igneous minerals were recrystallized extensively to neoblasts of approximately the same composition.
Where water/rock ratios were significantly higher and temperatures probably somewhat lower $\left(600^{\circ}-650^{\circ} \mathrm{C}\right)$, the original minerals were partly to completely replaced by brown and green hornblende to form amphibolite gneisses.

Although this deformation and metamorphism is concentrated in the upper $150 \mathrm{~m}$ of the core, narrow shear zones occur at several intervals deeper in the section. These shear zones obviously provided pathways for seawater to penetrate into the crust and to alter the rocks in the immediate vicinity of the faults. However, there is no evidence of extensive alteration of rocks associated with a "cracking front," as postulated by Lister (1974).

Because the brittle-ductile deformation and associated amphibolite facies metamorphism took place at high temperatures, it must have occurred shortly after the rocks crystallized beneath the ridge axis. We think that this high-temperature deformation reflects listric normal faulting along the rift valley walls. Lithologic Unit I, in which the rocks are extensively deformed, may represent a detachment surface that acted as the sole for the listric faults. Such listric faulting may also have caused considerable thinning of the crust, thus bringing the plutonic rocks to higher structural levels. The static alteration probably occurred contemporaneously with, 
or slightly later than, the deformation and amphibolite facies metamorphism.

These two phases of alteration are thought to have occurred while the crustal segment was beneath the inner rift valley floor. Currently, the rift valley on this portion of the Southwest Indian Ridge is about $8 \mathrm{~km}$ wide (Dick et al., this volume), and the half spreading rate is about $0.8 \mathrm{~cm} / \mathrm{yr}$ (Sclater et al., 1978). If the same conditions prevailed during 11 to $12 \mathrm{Ma}$, it should have taken a segment of newly formed crust about $500,000 \mathrm{yr}$ to migrate out of the inner rift into the flanking mountains. Dick et al. (this volume) estimate that by $50,000 \mathrm{yr}$, the entire section had solidified and cooled into the upper amphibolite facies, thus allowing subsolidus deformation to begin. Formation of brittle-ductile shear zones permitted deep penetration of seawater, leading to the formation of abundant amphibole and accelerating the cooling of the crust. Cooling and crustal thinning continued as the section moved across the rift valley floor. Early amphibole veins probably formed at this time, because some are cut by the foliation that was produced by brittle-ductile deformation.

By about 500,000 yr after formation, the crustal section had reached the edge of the inner rift and was being uplifted and transferred to the adjoining rift mountains. Transfer of the section out of the rift valley probably marked the end of brittle-ductile deformation and led to the formation of abundant inclined veins in response to release of stored and developing elastic thermal strain (Dick et al., this volume). These later veins took advantage of earlier amphibole veins, which were preferred locations for further cracking. About 1 m.y. after formation, the section had been completely transferred to the tectonic block being uplifted into the transverse ridge of the Atlantis II Fracture Zone; this uplift presumably accelerated the cracking initiated earlier.

Early high-temperature vein assemblages consist of diopside, hornblende, epidote, plagioclase, sphene, and zircon. These veins are similar to those reported from the Skaergaard intrusion by Bird et al. (1986), which have been attributed to simple brittle deformation associated with subsolidus cooling. Bird et al. (1988) showed that the formation of amphibole was favored where the vein fluids had low $\mathrm{Ca} / \mathrm{Mg}$ ratios, whereas diopside was favored where the ratios were high. Precipitation of amphibole can rapidly deplete the fluids in $\mathrm{MgO}$, thus causing diopside to form.

As the crust continued to cool, many of these veins were reopened, and low-temperature assemblages of calcite, zeolite, and clay minerals were deposited. The oxidative alteration of olivine is commonly associated with calcite veining and probably took place at about the same time. This reopen- ing of existing veins may have occurred during uplift of the section, perhaps in response to unloading by erosion. The subvertical, clay-lined fractures formed at approximately the same time.

\section{REFERENCES}

Batiza, R., and Vanko, D. A., 1985. Petrologic evolution of large failed rifts in the eastern Pacific: petrology of volcanic and plutonic rocks from the Mathematician Ridge area and the Guadelupe Trough. J. Petrol., 26:564-602.

Bird, D. K., Rogers, R. D., and Manning, C. E., 1986. Mineralized fracture systems of the Skaergaard intrusion, East Greenland. Meddelelser om Gronland, Geoscience, 16:1-68.

Bird, D. K., Manning, S., and Rose, N., 1988. Hydrothermal alteration of Tertiary layered gabbros. Am. J. Sci., 288:405-457.

Detrick, R. S., and Purdy, G. M., 1980. The crustal structure of the Kane Fracture Zone from seismic refraction studies. J. Geophys. Res., 85:3759-3777.

Fox, P. J., Detrick, R. S., and Purdy, G. M., 1980. Evidence for crustal thinning near fracture zones: implications for ophiolites. In A. Panayiotou (Ed.), Ophiolites: Proc. Int. Ophiolite Symp. Cyprus 1979: Cyprus (Geological Survey Dept.), 161-168.

Honnorez, J., Mevel, C., and Montigny, R., 1984. Geotectonic signifcance of gneissic amphibolites from the Vema Fracture Zone, equatorial Mid-Atlantic Ridge. J. Geophys. Res., 89:11379-11400.

Ito, E., and Anderson, A. T., Jr., 1983. Submarine metamorphism of gabbros from the mid-Cayman Rise: petrographic and mineral constraints on hydrothermal processes at slow-spreading ridges. Contrib. Mineral. Petrol., 82:371-388.

Kristmannsdottir, H., 1979. Alteration of basaltic rocks by hydrotheraml activity at $100-300^{\circ} \mathrm{C}$. Proc. 6th Int. Clay Conf., 359-367.

Lister, C.R.B., 1974. On the penetration of water into hot rock. Geophys. J. Royal Astron. Soc., 39:465-509.

Mevel, C., 1988. Metamorphism in oceanic layer 3, Gorringe Bank, eastern Atlantic. Contrib. Mineral. Petrol., 100:496-509.

Robinson, P. T., Flower, M.F.J., Schmincke, H.-U., and Ohnmacht, W., 1977. Low temperature alteration of oceanic basalts, DSDP Leg 37. In Aumento, F., Melson, W. G., et al., Init. Repts. DSDP, 37: Washington (U. S. Govt. Printing Office), 775-793.

Robinson, P. T., Von Herzen, R., et al., 1989. Proc. ODP, Init. Repts., 118: College Station, TX (Ocean Drilling Program).

Sclater, J. G., Dick, H.J.B., Norton, I., and Woodroffe, D., 1978. Tectonic structure and petrology of the Antarctic Plate Boundary near the Bouvet Triple Junction. Earth Planet. Sci. Lett., 36:393400.

Vanko, D. A., 1986. High-chlorine amphiboles from oceanic rocks: product of highly saline hydrothermal fluids? Am. Mineral., 71:5159.

Date of initial receipt: 23 April 1990

Date of acceptance: 12 September 1990

Ms 118B-122 

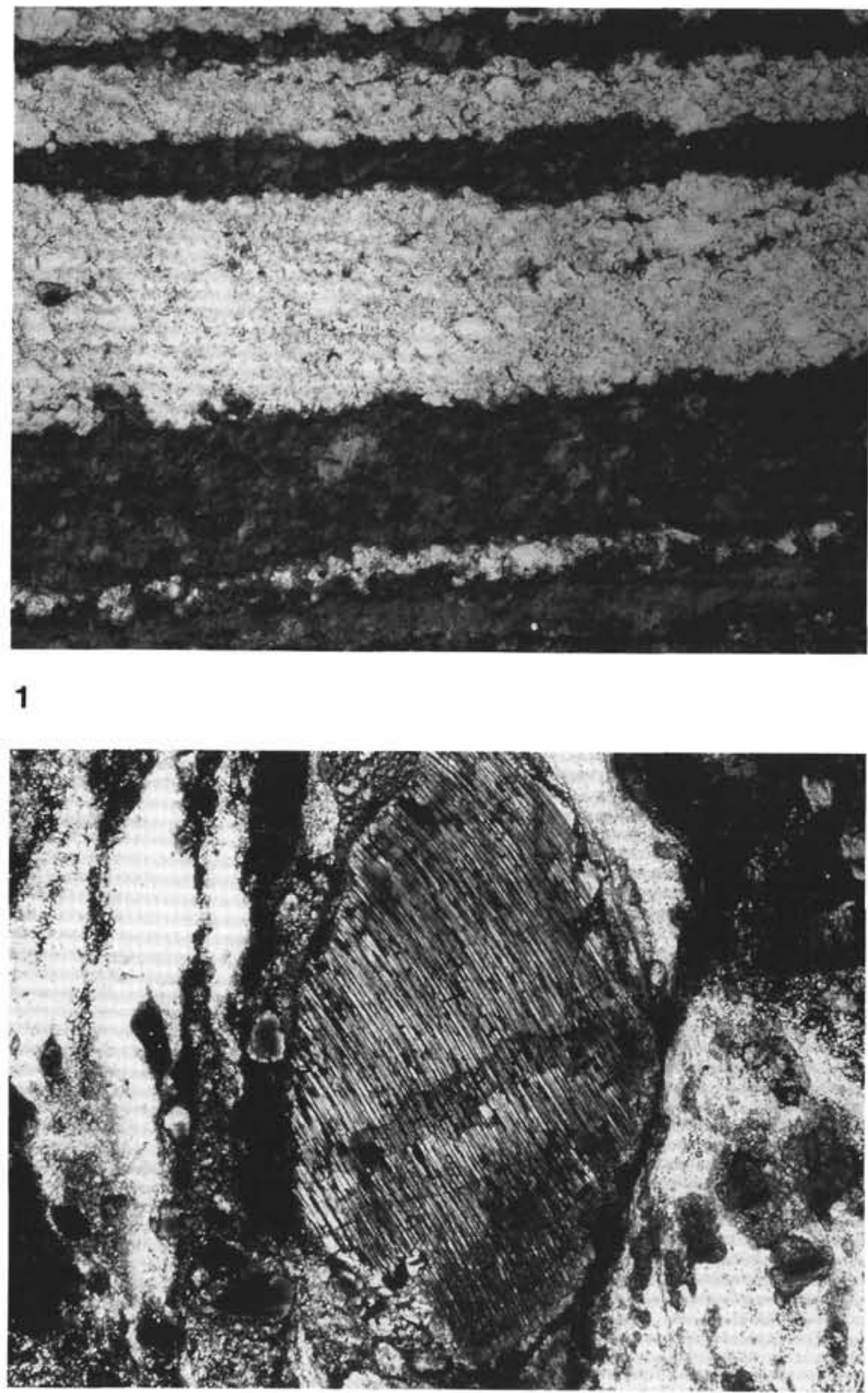

Plate 1. 1. Highly foliated amphibole gneiss. Dark bands are hornblende and light bands are plagioclase (Sample 118-735B-16R-1, 128-137 cm). 2. Narrow hornblende vein offset by foliation in deformed gabbro. Foliation is defined by amphibole (dark bands) and plagioclase (light bands)(Sample 118-735B-2D-1, 123-127 cm). 3. Large pyroxene porphyroclast in foliated metagabbro. Foliation is defined by hornblende (dark bands) and plagioclase (light bands)(Sample 118-735B-6D-1, 10-20 cm), 4, Euhedral sphene crystal in felsic vein

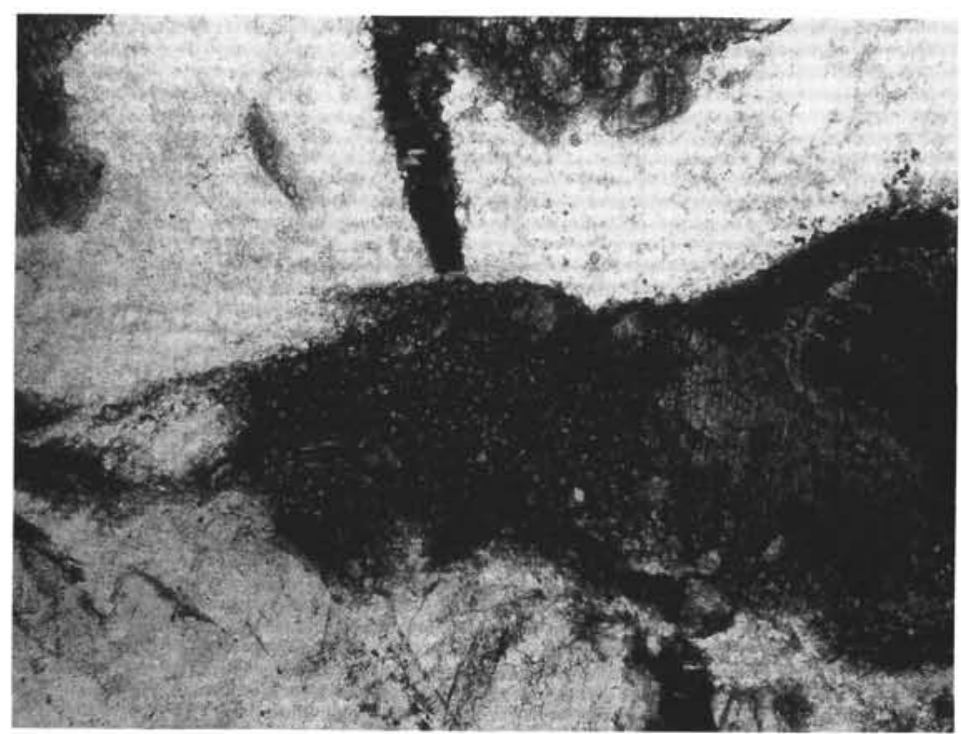

2

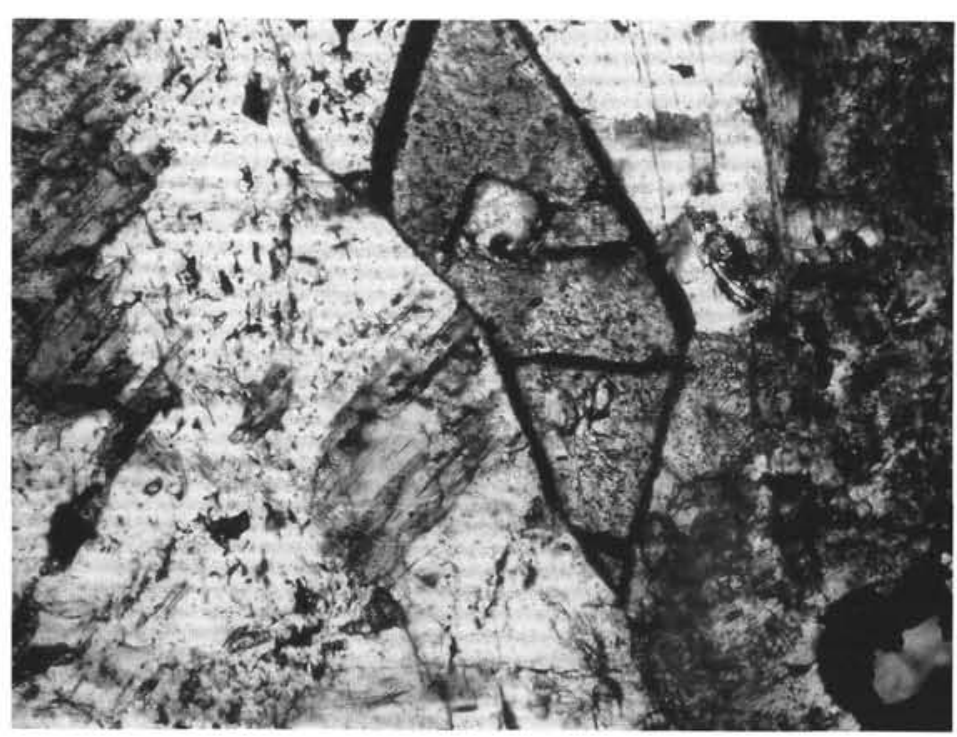

4 


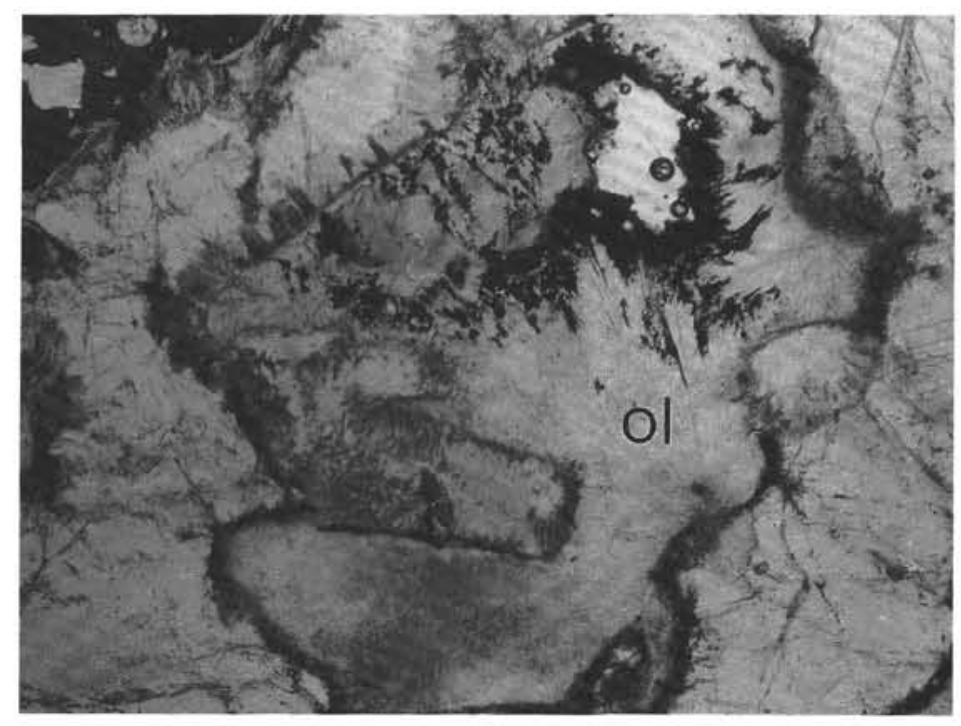

1

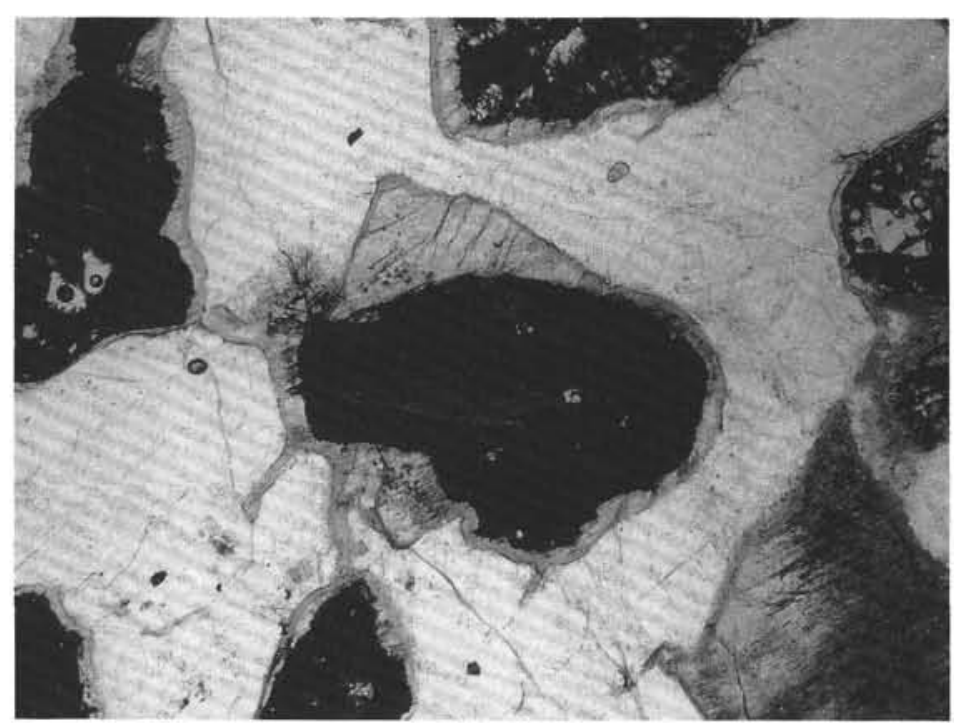

3

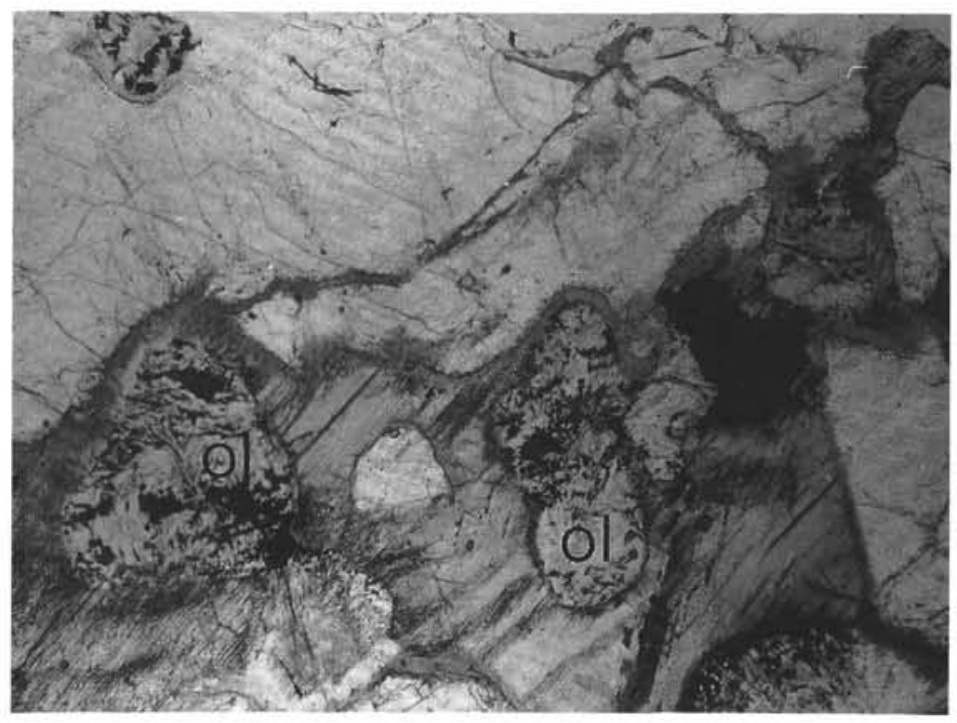

2

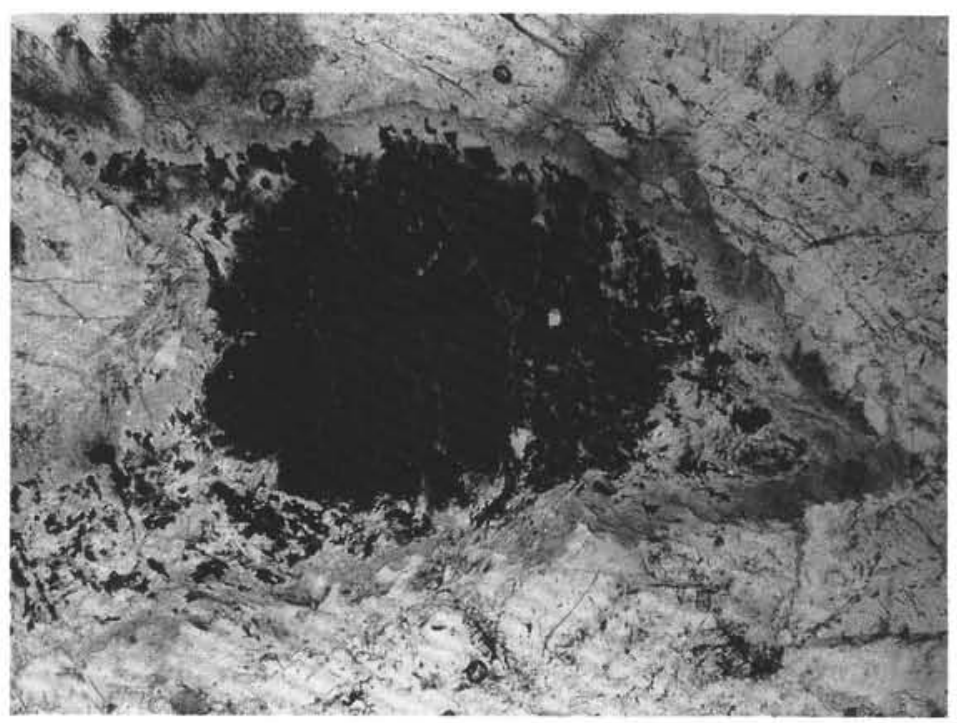

4

Plate 2. 1. Irregular olivine crystal pseudomorphed by tremolite, talc, and secondary magnetite as a result of static alteration. Olivine pseudomorph (Ol), outlined in black ink, is enclosed in plagioclase (Sample 118-735B-26R-3, 87-91 cm). 2. Small olivine crystals (Ol) completely pseudomorphed by talc, tremolite, and secondary magnetite. Pseudomorphs are completely enclosed in clinopyroxene crystals (Sample 118-735B-87R-7, 0-7 cm). 3. Olivine grain completely pseudomorphed by red, opaque oxides. Olivine grain is rimmed with clinopyroxene, which in turn has narrow rim of hornblende. Mafic grains are enclosed in plagioclase. Note partly altered olivine in upper right corner (Sample 118-735B-87R-7, 0-7 cm). 4. Olivine grain pseudomorphed by talc, tremolite, and secondary magnetite and opaque red oxide in center. Olivine was originally rimmed by talc and tremolite during static alteration and remaining core was replaced later by Fe oxides during oxidative alteration (Sample $118-735 \mathrm{~B}-63 \mathrm{R}-6$, $98-106 \mathrm{~cm}$ ). 


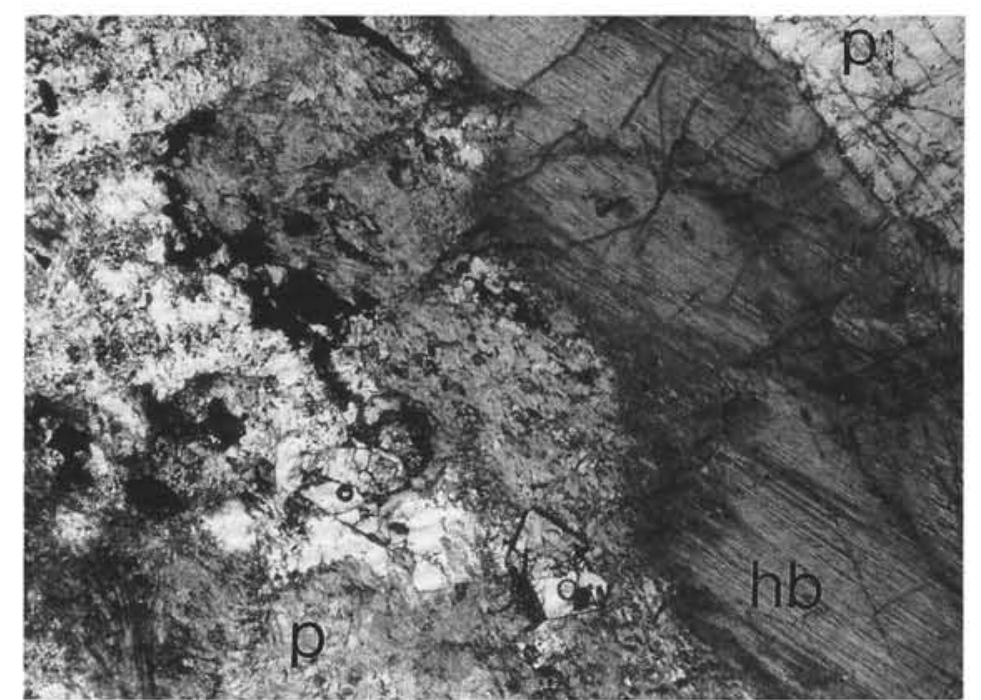

1

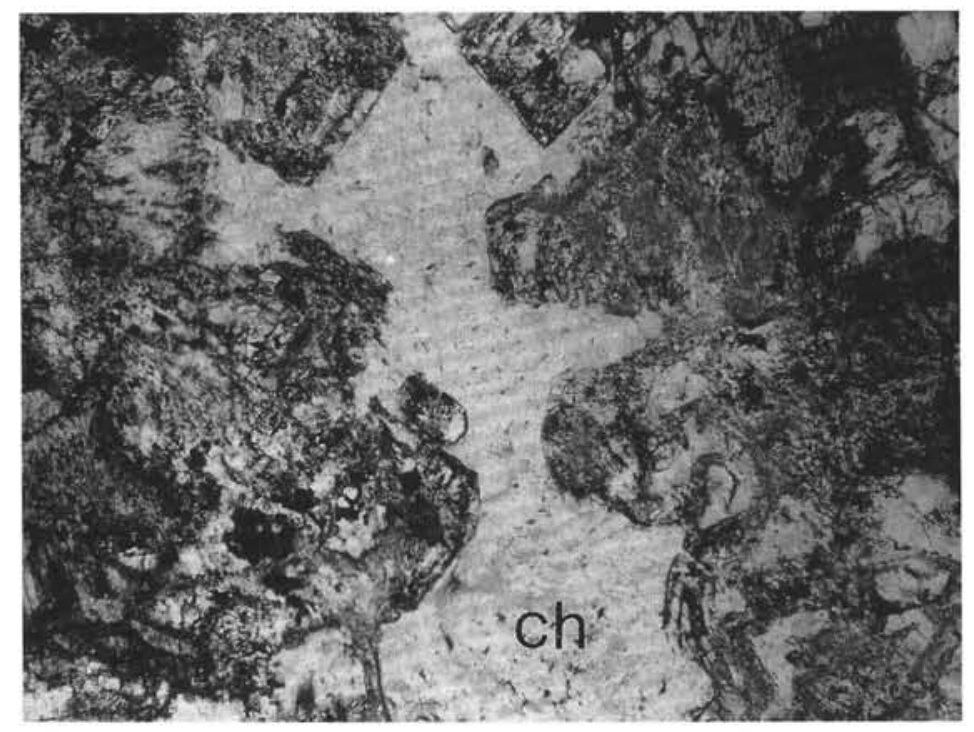

3

Plate 3. 1. Amphibole-plagioclase vein showing very sharp boundary with the primary minerals. Vein cuts primary plagioclase (pl) in upper right corner. Dark green hornblende $(\mathrm{hb})$ occurs along wall of vein with secondary plagioclase $(\mathrm{p})$ in central part (Sample 118-735B-84R-6, 31-41 cm). 2. Large, euhedral, zoned diopside crystals in vein. Zoning is in iron and magnesium. (Sample 118-735B-69R-5, 31-41 cm). 3. Irregular patch of light colored chlorite (ch) occurring in felsic vein (Sample 118-735B-69R-5, $31-41 \mathrm{~cm})$. 4. Irregular blocky crystals of epidote (ep) in plagioclase-diopside vein (Sample 118-735B-67R-2, 113-125 cm).

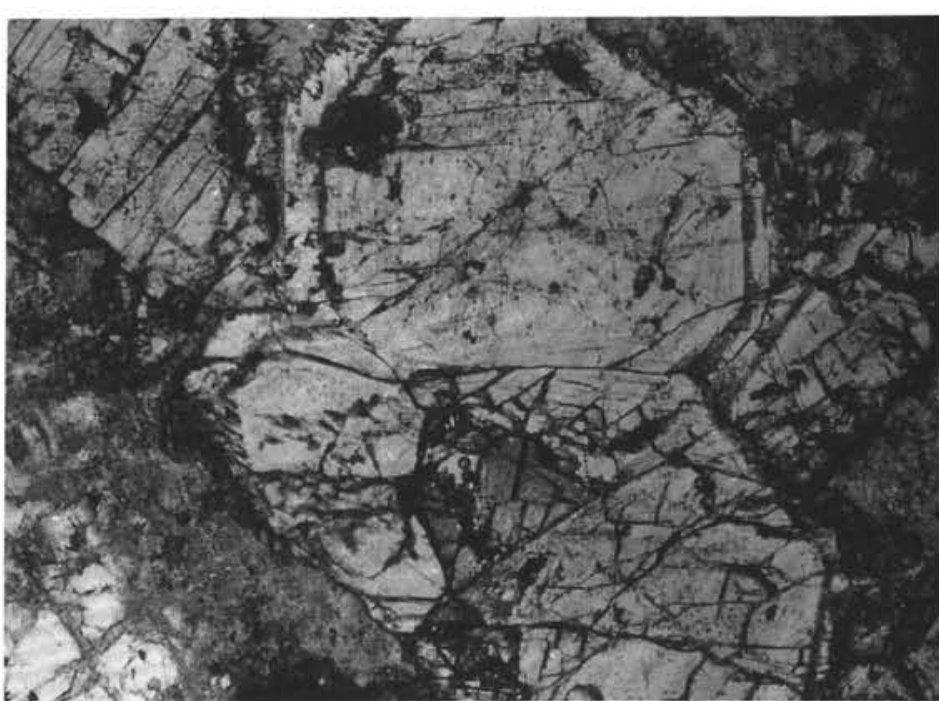

2

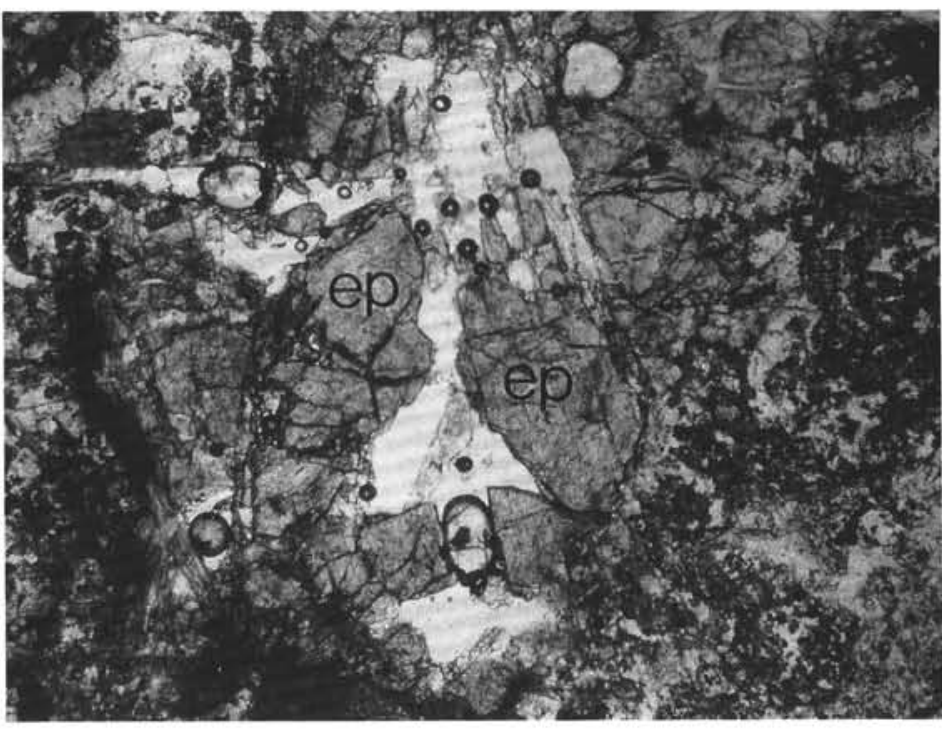

4 


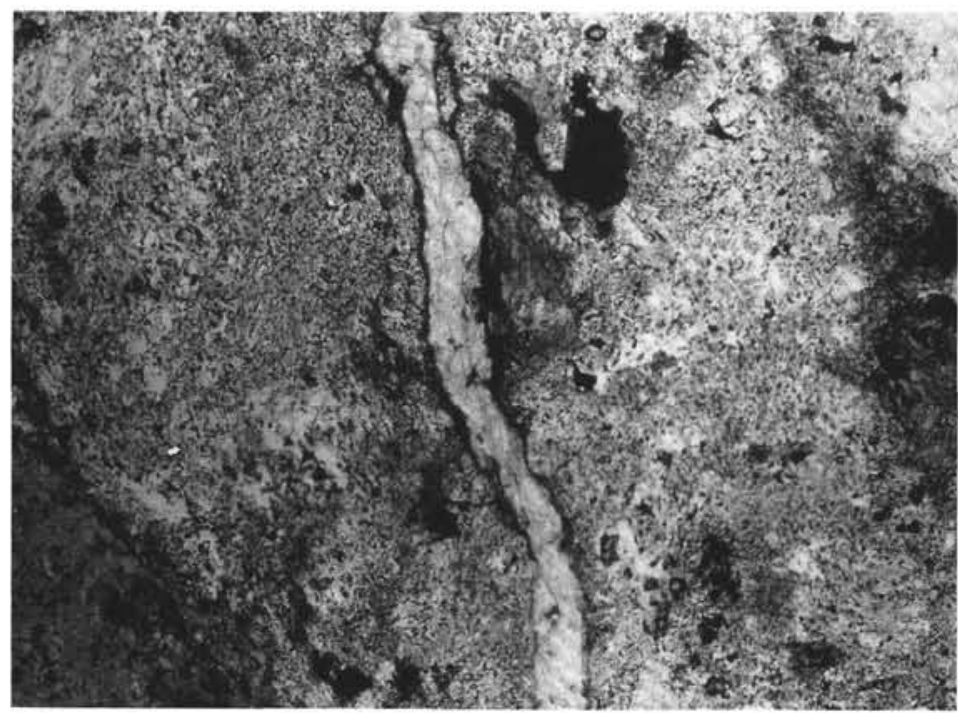

1

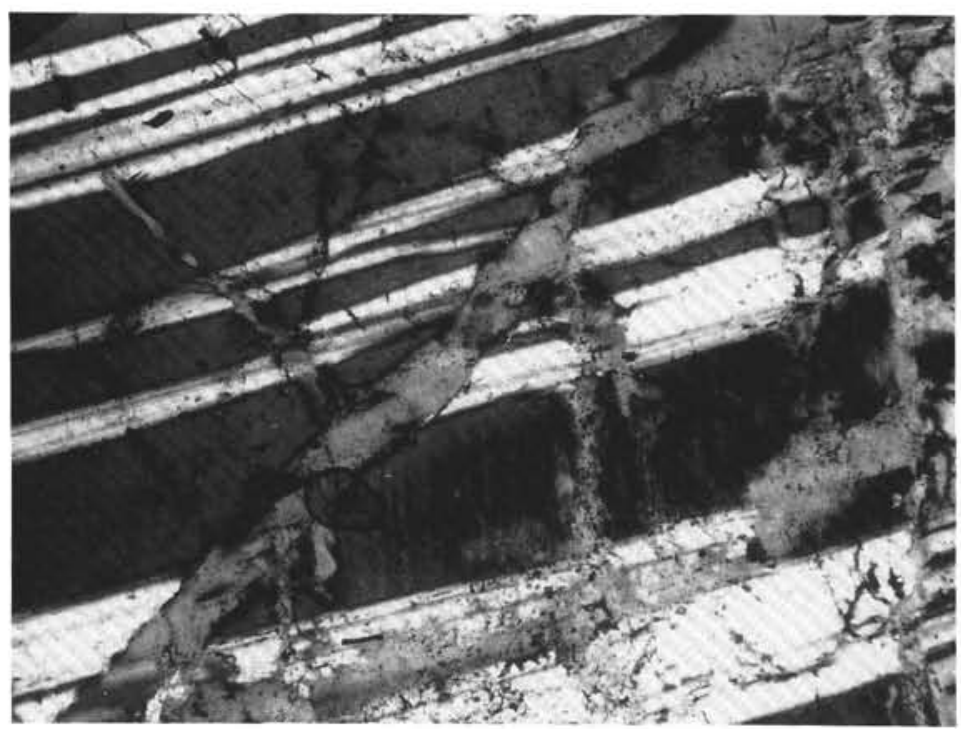

3

Plate 4. 1. Narrow zeolite vein cutting through center of felsic vein (Sample 118-735B-84R-6, 31-41 cm). 2. Narrow carbonate vein cutting through center of plagioclase-hornblende vein (Sample 118-735B-67R-1, 88-93 cm). 3. Irregular veins of secondary oligoclase cutting large primary plagioclase crystal (Sample 118-735B-35R-4, $13-20 \mathrm{~cm})$. 4. Irregular patch of zeolite $(\mathrm{ze})$ with minute needles of actinolite(?). Small round patch is chlorite $(\mathrm{ch})($ Sample $118-735 \mathrm{~B}-65 \mathrm{R}-3,0-6 \mathrm{~cm})$.

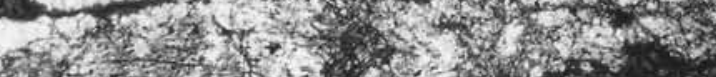

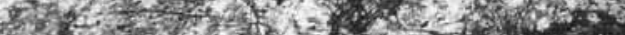
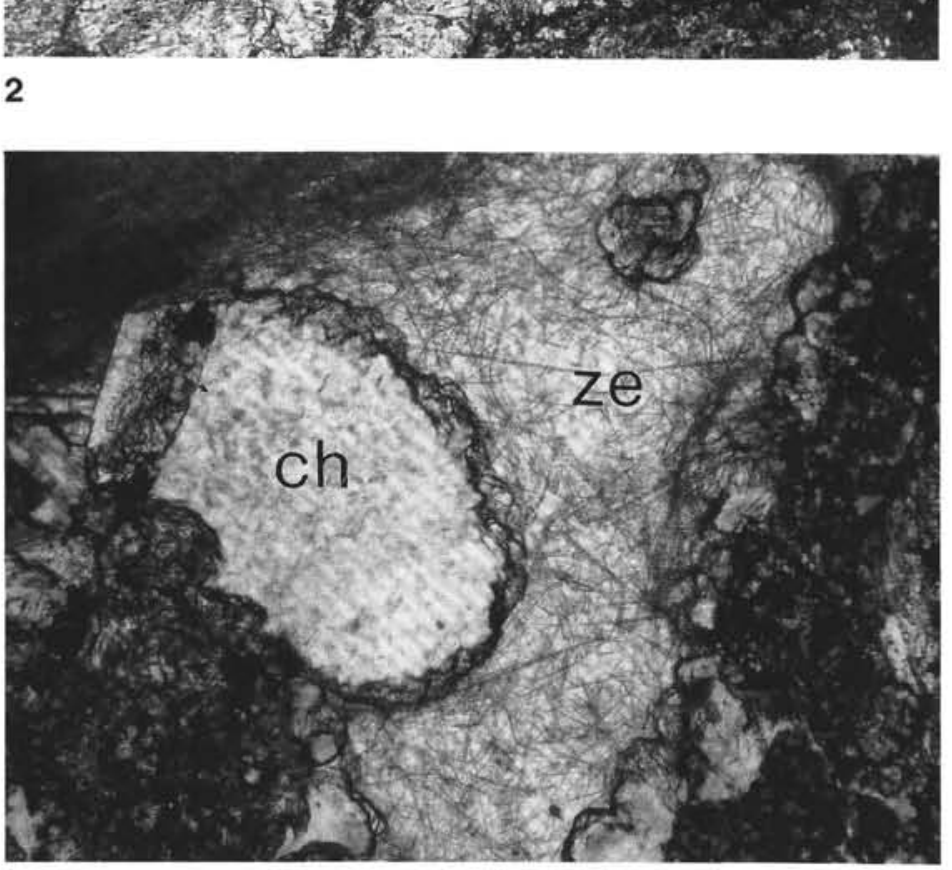